
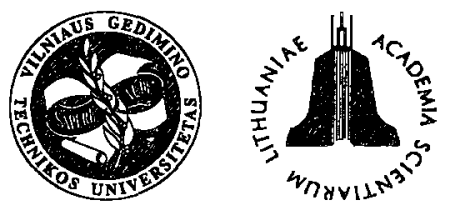

ISSN 1648-4142 TRANSPORT

http:/www.vtu.lt/english/editions

\title{
THE COMPARATIVE ANALYSIS OF ENGLISH AND LITHUANIAN TERMS OF TRANSPORT ENGINEERING
}

\author{
Valerija Marina \\ Dept of Foreign Language, Vilnius Gediminas Technical University, Sauletekio al. 11, LT-2040 Vilnius, Lithuania. \\ E-mail:vvka@vt.vtu.lt
}

Received 20020628 ; accepted 20021221

\begin{abstract}
The article presents the analysis of transport terms contained in the English - Lithuanian Dictionary of Automobile Transport and special texts. English terms are compared with their Lithuanian equivalents from the perspective of the theory of language relativity to identify universal and different patterns of expressing the same reality. All terms are classified into various groups according to this principle. It is also shown that an object expressed in Lithuanian by a single word may be denoted by multiple English words. Problems arising due to different approaches of speakers of different languages to objects of reality in giving names and classifying them are identified and some recommendations for their solution are given.
\end{abstract}

Keywords: automobile engineering; linguistic relativity; multidimensional phenomenon.

\section{Introduction}

Lexicographic problems make an important area of linguistic investigations, being recently marked by the appearance of new trends in compiling English - Lithuanian dictionaries [1]. These problems are particularly important for analyzing English technical terminology, its peculiarities and ways of translation into Lithuanian.

The aim of the present paper is to show how the meaning of English terms is expressed in Lithuanian, to identify most difficult cases, provide the explanation of the problems arising in working with the English terminology of transport engineering and give some practical recommendations for their solution. The material of the linguistic analysis is taken from the English - Lithuanian dictionary of automobile engineering terms [2] (about 2000 entries). Some interesting examples presenting translation difficulties which were encountered by the author in the years of translating experience are also included.

The analysis of the terms is performed within the framework of the theory of linguistic relativity formulated by the famous American researchers F. Boas, E. Sapir and L. Whorf [3-5].

Methods of semantic and stylistic analysis and basic principles of nomination are also used in the present investigation. As far as we know this approach to analyzing technical terms is new.

\section{Theoretical background}

Language relativity is multilevel and multidimensional. Language relativity is a multilevel and multidi- mensional phenomenon associated with the relation of language to thought, culture and reality as well as to encoding of reality by different languages.

Relativity has been defined differently, depending on the level considered. Thus, F. Boas [3] emphasized that ,the word expresses only part of an idea". This means that individual linguistic expressions are relative. He also gave many examples, showing how a given experience (reality) is differently rendered in various languages or how a set of experiences is differently grouped by different languages [3]. Here relativity may be interpreted as the absence of a single absolutely "correct" way of representing the reality by languages. This is the fact that cannot be denied, because different languages successfully perform their communicative function. E. Sapir [4] and B. L. Whorf [5] developed these ideas by adding the dimensions of thought, culture and view of the world as largely influenced by language. Major principles used in the present study are formulated as follows: „A given experience is differently rendered in various languages" [3]; „Every language is a vast pattern - system, different from other" [4].

These ideas are still popular in the West, being considered in modern papers [6].

\section{Discussion and Results}

It may seem that the easiest way for dictionary compilers is word for word translation of the English terms, especially taking into account that they convey new economic concepts often not found in Lithuanian literature. The analysis shows that this pattern is represented on a 
large scale, but it is not (and can not be in view of the theory of linguistic relativity) universal. Here are some examples:

control handle - valdymo rankenè $\dot{e}$;

continuous discharge - nenutrükstama iskkrova;

cooling mixture - aušinimo mišinys;

copper - asbestos gasket - vario- asbesto tarpiklis;

crankcase compression - spaudimas karteryje, etc.

Terms of this group constitute about $70 \%$ of the total number (about 2,000) of entries.

The second group includes terms representing similar pattern, with the only exception that an English term is structurally incomplete, with one or more words missing, but their meaning included in the semantic structure of the term. Conventionally, these terms may be called "compressed". In Lithuanian, however, their structure is completely restored (on the basis of dictionary definitions and the consultant's advice), e.g.

adaptor - type bearing - supimosi guolis su sutvirtinamaja mova' plotas;

contact area of tyre - padangos ir kelio salyčio

bare engine - variklis su pagalbiniu agregatu;

closed car-automobilis su uždaru kébulu.

adhesive force - molekulinio sukibimo jegga, eic.

It is evident that the missing words are reconstructed in the Lithuanian terms for the sake of clarity, though the same abridged pattern can be observed in the Lithuanian language, e.g. greitoji (pagalba); kontrolinis (darbas); pašaliniai (žmonès), etc., but mainly in the colloquial speech to denote commonly known concepts. This group constitutes about $4 \%$. The third group of ierms (about $6 \%$ ) consists of borrowings (anglicisms), e.g.

diaphragm carburettor - diafragminis karbiuratorius;

absorption - absorbcija;

detonation - detonacija;

(oil) circulation - (alyvos) cirkuliacija;

container - konieineris;

consistency - konsistencija, etc.

The fourth group of terms is represented by words and collocations in which the same concept is expressed quite differently in the English and Lithuanian languages, e.g.

absorption combustion - pagreitintas ${ }^{2}$ degimas; common transport - visuomeninis transportas; correct mixture - normalus mišinys;

dim light - „trumpoji" šviesa (žibintu);

eddy -free front - aptakus priekis (automobiliu);

free handle - nuimama rankena, etc.

Terms of this type make about $20 \%$ of the total num-

${ }^{1}$ Underlined words are not included in the original English terms.

${ }^{2}$ Underlined words convey the same idea which is expressed differently in English and Lithuanian. ber of dictionary entries.

What tendencies can be observed in the Lithuanian not word for word translation equivalents compared to the English originals?

First, emotionally charged words having a semantic element of "evaluation" or metaphoric expressions are usually replaced by neutral components (compare: bare engine - variklis su pagalbiniu agregatu; baby car mažalitražis automobilis; axial play - ašinis laisvumas, etc.)

Second, words that seem to the compilers not sufficiently informative are replaced by others, defining the concepts more precisely from their point of view (e.g. blended fuel-degalai su antidetonatoriumi; conventional oil - alyva be priedu; adverse - weather lamp - rüko žibintas, etc.).

A conclusion may be drawn that the Lithuanian equivalents often reflect an altemative approach to nomination determined by viewing the same things from various perspectives. They are also determined by the rules governing the Lithuanian language as a system. Thus, neutral unemotional terms seem to be more rational as well as more appropriate for Lithuanians than emotional metaphorical structures, when teminology is concerned. But when such changes are made the implications of the original terms have been lost. In fact only usage may show whether the translation changes are justified.

According to another statement of the theory of linguistic relativity, languages differently classify (group) the objects of reality. It may be illustrated by the following examples where multiple English words correspond to a single word in Lithuanian meaning the entire number of transport facilities:

$\left.\begin{array}{crl} & \text { English } & \multicolumn{2}{c}{\text { Lithuanian }} \\ \text { car } & \text { park } & \text { automobiliu } \\ \text { bus } & \text { fleet } & \text { autobusu } \\ \text { rolling } & \text { stock } & \text { vagony }\end{array}\right\}$ parkas

We can observe that "transporto parkas" has a number of different names compared to one name in Lithuanian, depending on the type of transport facilities. This implies that one concept underlying the name in Lithuanian is subdivided into several ones where different words mean somewhat different objects belonging to the same category. Compare also English and Lithuanian names for the driver's compartment:
English
Lithuanian

$\begin{array}{llll}\text { (car) driver's } & \text { cab } & \text { vairuotojo } & \\ \text { pilot's } & \text { cockpit } & \text { lakūno } & \text { kabina } \\ \text { elevator } & \text { car } & \text { lifto } & \\ \text { flight } & \text { compartment } & \text { (lekktuvo) igulos } & \end{array}$


Again, one word in Lithuanian corresponds to several words in English.

\section{Conclusions}

The Lithuanian equivalents of terms in transport engineering were divided into the following groups:

1) word for word translations;

2) borrowings (anglicisms);

1) reconstructed equivalents of English „compressed" terms;

2) terms based on completely different pattern for denoting the same concepts that are expressed by the English versions.

It is quite evident that terms of the first three groups follow the patterns of the English originals. Group 4, though not most representative (about $20 \%$ ), is very important to understanding major differences between the two languages from the perspective of nomination. Thus, the Lithuanian language chooses different characteristics of objects as well as avoiding associative links as the basis of nomination. On the contrary, a lot of the English terms of this group are metaphoric, based on associations not common to Lithuanians. This presents major comprehension and translation difficulties, because word for word translation of such terms often makes no sense for the speakers of Lithuanian. Therefore, their Lithuanian equivalents are neutral expressions appealing to consciousness rather than emotions.

A part of English terms, being translated into Lithuanian, lose their status because the Lithuanian equivalents are in fact extended definitions, but not terms commonly perceived as individual words or collocations. This raises the problem of creating the appropriate terminology in Lithuanian (like such compact terms as center cross - kryžma; baggage hold - bagažine, etc.).
A demonstration of language - relativity - based analysis to students may help them understand the alternative ways of nomination existing in other languages, thereby giving ,native speakers insight", while the study of metaphors will contribute to developing more flexible thinking habits based on associations. This in turn will facilitate looking for practical solutions of difficulties.

Further studies of transport engineering terms are needed. We think that, to become usable, dictionary entries shall and will undergo transformations, thereby acquiring more characteristics of "real" terms rather than being entirely dictionary definitions.

Examples of different classifications of the same objects of reality provided will help students to understand the specific ways of grouping and subdividing items in various languages. They will be aware that not always one Lithuanian word may be used to denote an item that seems integral to them, because English - speaking people see several similar but distinct objects here.

\section{References}

1. Vaičenoniené, J. New Lexicographic Trends in English Lithuanian Dicitionaries. Language Teaching / Learning in the Context of Social Changes, No 1, Kaunas: Technologija, 2000 , p. 3-9

2. Adomènienè, E. Anglu - lietuviu kalbu autotransporto terminų žodynas. Vilnius: VISI, 1976.

3. Boas, F. Language and Culture. New York, 1966. 218 p.

4. Sapir, E. Language. New York, 1964. 312 p.

5. Whorf, B. L. Language, Thought and Reality. Selected Writings. Massachusetts. USA, 1979. 252 p.

6. Lucy, J. A. Language Diversity and Thought. Cambridge University Press, 1992. $264 \mathrm{p}$. 